\title{
The Improvement and Innovation of Education Talent Training Mode with the Craftsman Spirit
}

\author{
Jin Wang \\ Chengdu Polytechnic, Chengdu, Sichuan, 610000, China
}

Keywords: Craftsman spirit; Vocational education; Talent training innovation

\begin{abstract}
Vocational colleges are important places for the cultivation of skilled talents in China. It is of positive significance to promote the development of education in our country, which is guided by the spirit of craftsman to cultivate students' professional qualities. These qualities includes dedication, rigorous and meticulous and the pursuit of excelence. The author deeply analyzes the importance of the craftsman spirit in the development of vocational education. The author also puts forward solutions in the establishment of cultivating vocational education mode and constructing double main body of modularized course system. And the author also advocates teachers should have high quality with some concrete measures.
\end{abstract}

\section{Introduction}

In recent years, with the development of China' s economy and the deepening reform of education, education in our country has made great progress. As an important part of the education system in China and under the restriction of traditional education idea and other factors, it has more necessity to improve vocational education personnel training mode. The reason for this necessity is that a lot of vocational education of the students' comprehensive quality and ability can not meet the effective demand of our society. Under the impetus of innovation-driven strategy, we should take the spirit of the craftsmen of the great power as the leading role and make more innovative and professional education talent training mode, which can improve the quality of the talents in professional skills. What's more, it is of great practical significance to promote the healthy development of education training mode, so that the talents can better meet the needs in society.

\section{The Practical Necessity for the Reform in Talent Cultivation Mode of Professional Education}

The spirit of craftsman has practical necessity in promoting the reform and innovation of professional education training mode, and the craftsman spirit is mainly manifested in the following aspects. As is shown in Fig. 1: 


\begin{tabular}{|l|}
\hline The \\
Practical \\
Necessity \\
for the \\
Reform in \\
Talent \\
Cultivation \\
Mode of \\
Profession \\
al \\
Education \\
\end{tabular}

Figure 1. Finite The Practical Necessity for the Reform in Talent Cultivation Mode of Professional Education

It is the Inevitable Requirement of Education Reform and Development of Modern Profession with the Craftsmen Spirit of Great Power. The fundamental purpose of education is to train practical and skilled talents, which can meet the needs of society. For deepening the reform of vocational education, ministry of education enacted implementation opinions, which aims to improve the quality of personnel training. The implementation opinions also aims to train the students' vocational skills and professional quality. Besides, the opinions also attaches great importance to develop students' spirits of dedication, integrity, and innovation. According to this guidance, the modern vocational education should get rid of attaching great importance to vocational skills training and despise the cultivation of professional quality in the past. The modern vocational education should cultivate students' vocational skills, strengthen their professional quality and the cultivation of their innovative spirit. Only in this way the modern vocational education can promote the students' all-round development and make it more in line with the effective demand of companies in choosing and employing persons. Taking the spirit of craftsman as the leading principle, vocational education aims to explore students' professional skills and to create effective ways in the improvement of professional quality and development. What's more, this way also has a far-reaching influence in the innovation of vocational education mode of students and can deepen the reform of modern vocational education.

It is the Practical need to Promote the Students' Ability of Professional Education with the Spirit of the Craftsmen. As an form of education, vocational education is different from the ordinary higher education. vocational education aims to product and develop skilled talents for an enterprise in further development and prosperity. The skilled talents should understand in technology, rich in knowledge, love in job and also should have innovation consciousness. Only with a strong sense of professionalism and pragmatism, students can adapt to the needs of the job better and effectively deal with the difficulties encountered in the future work. In the guidance of the craftsman spirit, vocational education personnel training should consider the students' professional ability and cultivation requirements, which conforms to the development in our current times. And vocational education personnel training is conducive to comprehensive development of students' vocational skills and professional quality, which can provide an important condition for the students in the fierce employment competition in the future .

It is the Realistic need to deepen the Cooperation and Development of School and Enterprise with the Spirit of the Craftsmen. Improving the vocational education with the spirit of the craftsmen, it is not only beneficial to the improvement of students' comprehensive quality ability, but also plays an important role in deepening school and enterprise cooperation. One is that putting the spirit into the vocational school in daily teaching. This way can transform the vocational education' $s$ attention from the cultivation of students' professional skills in the past to attach 
importance to combine students' professional knowledge, professional skills with professional literacy. Putting the spirit into the vocational school also make vocational education in personnel training more conform to the actual needs of enterprises, and putting the spirit into the vocational school also make it better to improve the social reputation and influence of vocational education. Therefore, the vocational education can has a long-term development. On the other hand, the sustainable development of enterprises cannot be separated from the support of high-quality applied talents. Because talents are the key to enterprise development. According to incomplete statistics, there are 5,000 enterprises with more than 200 years of development in the world, mainly in countries such as Britain, France, Japan and Germany. These companies all take the craftsman spirit as the soul of enterprise survival and development in common. And these enterprises pay attention to the employees in the cultivation of professional ethics, qualities and spirits, and also pay attention to the all-round development of staff abilities. At the same time, the enterprise also requires employees to understand and identify with the culture of the enterprise, love their work, be honest and practical, and also should have a strong sense of teamwork and cooperation. This is of great significance in the long-term development of enterprises. In addition, employees are required to be able to master skills and have a strong sense of dedication in work, which is also greatly important for improving the production efficiency and reducing the cost of enterprises.

\section{The Main Measures for the Reform and Innovation of the Professional Education Talent Training Model with the Spirit of the Craftsman}

The spirit of the craftsman has provided important guidance for deepening the reform of education and accelerating the innovation of professional education in talent training mode. The tasks should be done from the following aspects, as are shown in Fig. 2:

\begin{tabular}{|c|c|c|}
\hline \multicolumn{3}{|c|}{$\begin{array}{l}\text { The main measures of the reform and } \\
\text { innovation of the talent training mode in } \\
\text { vocational education }\end{array}$} \\
\hline We should play the & We should play the & \\
\hline basic role of the & basic role of craftsman & the basic role of \\
\hline craftsman spirit & spirit and construct the & craftsman spirit \\
\hline and construct a & professional education & and build a \\
\hline pattern of talent & curriculum system & high-quality \\
\hline cultivation & which is the core of & professional \\
\hline dominated & cultivating & education \\
\hline double directions & professional & teachers team \\
\hline and agents & ability & \\
\hline
\end{tabular}

Figure 2. Finite The main measures of the reform and innovation of the talent training mode in vocational education 
We Should Play the Basic Role of the Craftsman Spirit and Construct a Pattern of Talent Cultivation Dominated by Double Directions and Agents. According to the characteristic of vocational education and practical situations, vocational education wants to make the students can better adapt to the social needs and meet the companies' standards in choosing and employing persons in the future, and vocational education also wants to constantly improve student' $s$ competitiveness in employment. Therefore, based on the basis of craftsman spirit, vocational schools should insist on developing the innovative training mode and giving full attention to the advantages of schools and enterprises, and as well as accelerating the process of school curriculum and constructing practice bases. Besides, vocational schools should build the double main body and combine schools and enterprises for the new mode in vocational education personnel training. Vocational schools should also combine with the actual situations, set up professional construction committee, hold meets regularly for studying the professional construction and development. Besides, vocational schools should discuss personnel training, industry development and curriculum system construction. This kind of training mode is greatly different from the traditional vocational education training mode. In this new type of talents training mode, this new mode is pay more attention to the cultivation of student' s professional qualities and professional spirits, and it has realized the organic combination with students' knowledge, skills, experience and other various aspects. By strengthening the cultivation of the basic knowledge, professional skills, strengthening students in behavior, mind and other good professional qualities in daily teaching, the new model aims to promote the ability of the students' comprehensive qualities. And about these qualities, these can help students better realize theirs own values in the later work.

Play the Basic Role of craftsman's Spirit and Construct the Professional Education Curriculum System which is the core of Cultivating Professional Post Ability. In order to play a fundamental role with craftsman spirit in the construction of vocational education courses, vocational education must focus on building modular curriculum system. And vocational education should do further research of the enterprise, understand the basic situation of the entry crowd and the promotion crowd. At the same time, vocational education construction needs to analyze the basic requirements and vocational skills of different positions. Besides, vocational education construction also needs to formulate the target and plan for professional personnel training. With the students' training needs in professional ethics, professional spirit, professional attitude and abilities related to career development, vocational education construction should integrate the professional standards with ethical standards for modular curriculum system with the spirit of craftsman. Vocational education curriculum construction mainly includes the following aspects: one aspect is to strengthen the professional basic theoretical knowledge to the students in vocational colleges. Strengthen the professional basic theoretical knowledge to the students should strengthen the student' education in thought and theory, career development planning and other public basic courses education, and also should strengthen the cultivation of students' ideological knowledge for developing their comprehensive quality. By this way of vocational education can guide students to set up the correct outlook about life and world, and vocational education also can make students form a positive personality and hardworking attitude in life. Second is the specialized course module. The construction of vocational education should be combined with the students' professional requirements, should focus on the cultivation and training of professional theoretical knowledge and skills, and realize the organic combination of theory and practice. Third is vocational and technical modules. Vocational education construction should focus on students' core professional courses, and proceed the teaching process with the spirit of the craftsman in daily teaching. At the same time, vocational education construction should combine students' professions with the practical situations, guide the student to develop characters of honest, trustworthy and pragmatic innovation. Besides, vocational education construction should train the students in the practice for not fearing hardship, difficulty and grasp the willing quality, and also should let the students deeply understand the connotation of the craftsman spirit. Four is professional development module. This aspect mainly means students to work with the professional qualification exam, the purpose of this module is to improve the students' comprehensive ability, the professional 
development and career potential migration ability. By this way, the student can occupy the advantageous position in the fierce competitions and students also can better realize the life goals and values in the future.

Play the Basic Role of Craftsman Spirit and Build a High-quality Professional Education Teachers Team. In improving the teaching mode of innovative professional education and the training quality of professional talents, the high-quality professional education teachers team has a fundamental role. It is important to cultivate a team with high comprehensive quality, because the high-quality professional education teachers team is an important measure and content to deepen the reform and innovation in education talent training. Professional education teachers include basic theory course teachers, practical training course teachers, and some part-time teachers with on-the-job training experiences. The construction should strengthen the training to the teacher team, and must constantly improve the teacher teaching level and the practical ability. At the same time, the construction should strengthen the guidance on teachers' professional attitude, responsibility awareness and dedication, and play the role of teachers.Besides, teachers also should use practical actions to influence and infect students, and help students to cultivate the positive professionalism and excellent technical skills. Only in this way the construction of the high-quality professional education teachers team can let the student keep craftsman spirit firmly in mind and heart, and make the students take the spirit as the soul of their own work in the future.

\section{Acknowledgement}

This research is supported by the foundation the Research Results of 2017 College-Level Scientific Research Project of Chengdu Polytechnics (granted by 17CZYR0223).

\section{References}

[1] Tang Y, Ji A Q. The cultivation of craftsman's Spirit in higher Vocational Education[J]. Journal of Nantong University (Social Sciences ), 2017 (1) :142-148.

[2] Cheng H T. The absence of craftsman's Spirit and the Mission of Vocational Colleges [J]. Vocational Education Forum, 2016 (22):79-82.

[3] Li H C. Research on the cultivation and Promotion of "artisan Spirit" under the background of supply-side reform[J]. Vocational Education Forum, 2016 (16) :33-37+96.

[4] Tao W H, Ma G X. Practical Research on Talent training of Vocational Education based on the Spirit of craftsman[J]. Vocational Education Forum, 2017 (2) :60-64.

[5] Gao L. On the application of teaching design in College English teaching [J]. China Educational Technology. 2012(07): 133-137.

[6] Gannod G C, Burge J E, Helmick M T. Using the Inverted Classroom to Teach Software Engineering [A]. ICSE'08[C]. New York,2008: 777-786.

[7] Strayer J F. How Learning in an Inverted Classroom Influences Cooperation, Invocation and Task Orientation [J].Learning Environment Res,2012(15): 171-193.

[8] Christine Bauer-Ramazani, John M. Graney, Helaine W. Marshall, Christine Sabieh. Flipped Learning in TESOL: Definitions, Approaches, and Implementation [J]. TESOL Journal 7.2. 2016(6): 429-437.

[9] Pan Bc. An Experimental study on the Application of the flipping classroom Model in the Teaching of Colleges and Universities [J]. e-Education Research. 2015(3): 83-88.

[10] Deng D. Review on the Application of flipping classroom Model in College English Teaching [J]. Foreign Language World. 2016(4): 89-96. 